\title{
Subjective sleep quality and its etiology in the emergency department
}

\author{
Jean-Marc Chauny, MD, MSc ${ }^{*}$; Jean Paquet, $\mathrm{PhD}^{*^{\ddagger}}$; Julie Carrier, $\mathrm{PhD}^{\ddagger}$; Gilles Lavigne, $\mathrm{DMD} \mathrm{PhD}^{\ddagger}$; \\ Martin Marquis, MSc*; Alexis Cournoyer, $\mathrm{MD}^{*}{ }^{\dagger}$; Christiane Manzini ${ }^{\S}$; Raoul Daoust, MD, $\mathrm{MSc}^{{ }^{\dagger}}$
}

\author{
CLINICIAN'S CAPSULE \\ What is known about the topic? \\ Most hospital settings do not provide an optimal \\ environment for sleep. \\ What did this study ask? \\ Assessed the subjective quality of nighttime sleep and its \\ affecting factors in the emergency department (ED). \\ What did this study find? \\ Subjective sleep quality was lower in the ED, as compared \\ with home sleep, and was affected by stress, noise, pain, \\ and stretcher comfort. \\ Why does this study matter to clinicians? \\ ED sleep is not optimal but can be improved, as the factors \\ disturbing it are potentially modifiable.
}

\section{ABSTRACT}

Objective: Patient sleep quality has a significant impact on recovery. However, most hospital units do not provide an optimal environment for sleep and there are currently no data available on how well patients sleep during their emergency department stay. The main objective of this study was to assess the subjective quality of nighttime sleep and factors that affect sleep in the emergency department (ED).

Methods: A prospective sample of patients aged 18 years and older who presented to the ED from July 2015 to October 2015 was investigated. All participants were on stretcher and slept at least one night in the ED. Participants were asked to complete a sleep questionnaire adapted to the ED environment on sleep quality and its potentially modifying factors.

Results: A total of 235 patients participated in the study (mean age: $64 \pm 20$ years, $51 \%$ women). Compared to the week at home prior to admission, subjective sleep quality was lower in the ED $(p<0.001)$ : almost half the participants took more than 30 minutes to fall asleep, and they reported waking up 3.5 times per night on average. Lower subjective sleep quality in the ED was associated with higher stress, noise, and pain, as well as with stretcher comfort and lower home sleep quality the week prior to admission.

Conclusions: Subjective sleep quality in the emergency department is not optimal, and is influenced by stress, noise, pain, and stretcher comfort, all potentially modifiable factors.

\section{RÉSUMÉ}

Objectif: La qualité du sommeil a une forte incidence sur le rétablissement. Toutefois, la plupart des services hospitaliers n'offrent pas un environnement favorable au sommeil, et il n'existe pas de données sur la qualité du sommeil des patients durant leur séjour au service des urgences (SU). L'étude visait donc principalement à évaluer la qualité subjective du sommeil durant la nuit ainsi que les facteurs qui ont une influence sur celui-ci au SU.

Méthode: L'étude a été menée sur un échantillon prospectif de patients âgés de 18 ans et plus, qui ont consulté au SU, de juillet 2015 à octobre 2015. Les participants étaient tous sur civière et avaient passé au moins 1 nuit au SU. On leur a demandé de remplir un questionnaire, adapté à l'environnement du SU, sur la qualité du sommeil et les facteurs susceptibles d'altérer celui-ci. Résultats: Au total, 235 patients ont participé à l'étude (âge moyen : $64 \pm 20$ ans; femmes : $51 \%$ ). La qualité subjective du sommeil était moins bonne que celle observée à domicile, durant la semaine précédant le séjour au SU $(p<0,001)$ : presque la moitié des participants ont pris plus de 30 minutes avant de s'endormir et ils ont déclaré s'être réveillés 3,5 fois par nuit, en moyenne. Une mauvaise qualité subjective du sommeil était associée à un degré élevé de stress, au bruit et à la douleur ainsi qu'à l'inconfort de la civière et à une qualité moindre du sommeil observée à domicile, durant la semaine précédant le séjour au SU. Conclusions: La qualité subjective du sommeil au SU n'est pas très bonne et elle est altérée par le stress, le bruit, la douleur et l'inconfort de la civière, tous des facteurs susceptibles de modification.

Keywords: emergency department, sleep, subjective sleep quality

From the *Department of Emergency Medicine, Research Centre, CIUSSS du Nord-de-l'île-de-Montréal, Hôpital du Sacré-Cœur de Montréal, Montréal, QC; and TFaculté de Médecine, Université de Montréal, Montréal, QC; and \#Centre for Advanced Research in Sleep Medicine, CIUSSS du Nord-de-l'Île-de-Montréal, Hôpital du Sacré-Cœur de Montréal, Montréal, Québec, Canada.

§Deceased.

Correspondence to: Dr. Jean-Marc Chauny, Emergency Department, Hôpital du Sacré-Cœur de Montréal, 5400 Gouin Blvd. West, Montréal, OC H4J 1C5; Email: jean-marc.chauny@umontreal.ca 


\section{INTRODUCTION}

Sleep contributes to several physiological functions, notably the immune, cardiovascular, metabolic, and endocrine systems. ${ }^{1,2}$ However, most hospitals do not provide an optimal environment for patient sleep quality, which may negatively impact recovery. For example, disrupted sleep has been associated with increased morbidity and mortality in intensive care unit (ICU) patients. ${ }^{3}$ In the ICU, polysomnographic studies indicate that nighttime sleep is short, fragmented by many wakefulness periods, composed of predominantly lighter sleep stages (1 and 2), and with almost no restorative slow-wave sleep. ${ }^{3-5}$ In general hospital units, a significant proportion of patients (46\%-91\%) also experience poor subjective sleep quality, as assessed with in-house sleep questionnaires or the Pittsburgh Sleep Quality Index. ${ }^{6-10}$

The most frequent factors associated with poor sleep in the ICU or hospital units are age, sex, smoking, anxiety, pain, noise, lighting, worries about their disease, other patients, staff disruption, medical equipment, medication, the illness itself, and bed comfort. ${ }^{3-10}$ Fortunately, some recent interventions have been proposed to improve sleep quality during hospitalization and have shown promising results. ${ }^{11}$

No data are currently available on subjective sleep quality in the emergency department (ED). The main objective of this study was to assess the subjective quality of patient nighttime sleep in the ED and its associated factors. It was hypothesized that subjective sleep quality in the ED would be significantly lower, as compared with the previous week at home. Moreover, lower subjective quality would be associated with modifiable factors (noise, light, and pain).

\section{METHODS}

\section{Study design and population}

This prospective observational cohort study was conducted in the ED of a tertiary care hospital with an annual census of approximately 65,000 ED visits (mostly adults). This study received approval from our institutional ethics review board.

\section{Participant selection}

A convenience sample of patients aged 18 years and older who consulted the ED from July 2015 to October
2015 was recruited according to the following inclusion criteria: 1) were on a stretcher; 2) slept at least one night in the ED; and 3) spoke French or English. Patients who were in the waiting or reanimation area during the night were excluded. Patients were recruited on weekday mornings (8:00 a.m. to noon) but had to arrive at the ED before 18:00 on the evaluated night.

\section{Measurements}

In the morning, after a night of sleep in the ED, participants were asked to complete a short sleep quality questionnaire adapted to the ED environment. ${ }^{12}$ It contained six questions on the participant's perceived quality of sleep in the ED and nine questions on certain factors that could have affected that sleep. Participants rated most questions on an 11-point numerical scale, ranging from 0 to 10 , for example, "How would you rate the quality of your sleep last night?" for which zero indicated very poor and 10 indicated excellent sleep quality.

\section{RESULTS}

A total of 235 patients agreed to participate in the study. Their mean age was $64 \pm 20$ years, and $51 \%$ were women. Subjective sleep quality in the ED was significantly lower than for the previous night at home (difference 1.4, 95\% confidence interval [CI] 0.89-1.86, $p<0.001$ ), indicating a $20 \%$ decrease in the numerical scale of sleep quality. On average, participants rated their sleep quality at $5.4( \pm 3.2)$, as compared with a score of 6.8 for the previous week at home. Almost onehalf the participants took more than 30 minutes to fall asleep, and participants reported waking up 3.5 times per night on average. Noise and stress had the highest mean scores among the proposed sleep disruption variables (Table 1). Using a stepwise multiple regression, stress $(11 \%)$, noise $(6 \%)$, pain (4\%), and stretcher comfort $(3 \%)$ were negatively associated with subjective sleep quality, whereas past week home sleep quality (1\%) was positively related. These five factors together explained $25 \%$ of the variance in subjective sleep quality.

\section{DISCUSSION}

This study is the first to assess sleep quality in an ED and showed that sleep quality was not optimal. 


\begin{tabular}{|c|c|}
\hline Variables & $\begin{array}{l}\text { Mean (SD) or } \\
\text { number (\%) }\end{array}$ \\
\hline \multicolumn{2}{|l|}{ Sleep variables } \\
\hline $\begin{array}{l}\text { 1) Sleep quality in the past week }(0=\text { very poor, } \\
10=\text { excellent })\end{array}$ & $6.8(2.6)$ \\
\hline $\begin{array}{l}\text { 2) Sleep quality last night }(0=\text { very poor, } \\
10=\text { excellent })\end{array}$ & $5.4(3.2)$ \\
\hline 3) Napped the previous day (yes) & $74(32 \%)$ \\
\hline 4) Time to fall asleep (>30 minutes) & $93(43 \%)$ \\
\hline 5) Number of awakenings & $3.5(3.8)$ \\
\hline $\begin{array}{l}\text { 6) Feeling awake in the morning }(0=\text { unable } \\
\text { to stay awake, } 10=\text { fully alert and awake) }\end{array}$ & $6.8(3.0)$ \\
\hline \multicolumn{2}{|l|}{ Factors that affected ED sleep } \\
\hline $\begin{array}{l}\text { 7) Noise level last night ( } 0=\text { very quiet, } \\
10=\text { very loud })\end{array}$ & $4.7(3.2)$ \\
\hline \multicolumn{2}{|l|}{$\begin{array}{l}\text { 8) Noises that affected sleep }(0=\text { not at all, } \\
10=\text { a lot })\end{array}$} \\
\hline Other patients & $2.8(3.4)$ \\
\hline Conversations & $2.3(3.1)$ \\
\hline Intercom & $1.9(2.8)$ \\
\hline Visits by hospital staff & $1.8(3.0)$ \\
\hline Monitors & $1.7(2.9)$ \\
\hline Alarms & $0.6(1.9)$ \\
\hline $\begin{array}{l}\text { 9) High-rated stress level last night }(0=\text { very } \\
\text { low, } 10=\text { very high) }\end{array}$ & $4.1(3.7)$ \\
\hline $\begin{array}{l}\text { 10) Worrying about the disease }(0=\text { not at all, } \\
10=a \text { lot })\end{array}$ & $3.6(3.9)$ \\
\hline 11) Stretcher comfort $(0=$ not at all, $10=a$ lot $)$ & $2.9(3.6)$ \\
\hline $\begin{array}{l}\text { 12) Uncomfortable medical apparatus }(0=\text { not } \\
\text { at all, } 10=\text { a lot })\end{array}$ & $2.8(3.6)$ \\
\hline 13) Light $(0=$ not at all, $10=$ a lot $)$ & $2.6(3.6)$ \\
\hline 14) Pain $(0=$ not at all, $10=$ a lot $)$ & $2.5(3.6)$ \\
\hline 15) Room temperature $(0=$ not at all, $10=a$ lot $)$ & $2.3(3.3)$ \\
\hline
\end{tabular}

Participants perceived 20\% lower sleep quality in the $\mathrm{ED}$, as compared with at home. Moreover, stress, noise, pain, and stretcher discomfort were perceived to affect sleep quality negatively.

The mean subjective sleep quality obtained in ICU studies $(4.7 \pm 2.3 \text { on a } 10 \text {-point numerical scale })^{12}$ was similar to that obtained in this study $(5.4 \pm 3.2$ on an 11-point numerical scale), suggesting that ED and ICU subjective sleep quality are comparable. The mean ED sleep quality in the present study was lower than the one found in a study of hospitalized patients using a similar sleep quality questionnaire (5.4 vs. 6.7 , respectively, on an 11-point numerical scale). ${ }^{13}$ The mean number of awakenings per night for our patients was also higher $(3.5 \pm 3.8$ vs. $2.2 \pm 2.4$, respectively), suggesting poorer ED sleep quality, as compared with a hospitalized setting. ED patients have less privacy and undergo more tests in a short timeframe, as compared with hospitalized patients. This could explain the similar quality of ED and ICU sleep.

The factors affecting sleep quality found in the present study, including noise, pain, and stretcher comfort, have been reported in previous ICU and hospital unit studies. $^{3-10,12,13}$ Stress during the night was the strongest predictor of lower subjective sleep quality. Anxiety ${ }^{8}$ and worries about the illness ${ }^{7}$ were previously shown to affect sleep quality significantly. In the ED, patients may not be fully diagnosed or not yet reassured by definitive treatment. Accordingly, effective pain treatment combined with adequate reassurance and a more sleep-friendly environment (low noise, low light, and fewer optional staff interventions) would improve the ED sleep experience. However, other unassessed factors in the present study may probably affect the patient's subjective sleep quality, as only $25 \%$ of the total variance in the multiple regression analysis was explained.

\section{LIMITATIONS}

The sleep questionnaire used in this study has not been previously validated in an ED population. The use of a non-random convenience sample (recruited on weekdays), sampling bias resulting from participation refusal, and recruitment from only one ED reduces the generalizability of the results.

\section{CONCLUSION}

Subjective sleep quality is less than optimal in the ED and negatively influenced by stress, noise, pain, and stretcher comfort. Optimizing certain sleep disruption variables could improve sleep quality in the ED.

Acknowledgements: The authors would like to thank Dominique Petit and Margaret McKyes for their contributions to the manuscript revision.

Competing interests: None declared.

\section{SUPPLEMENTARY MATERIAL}

To view supplementary material for this article, please visit https://doi.org/10.1017/cem.2018.394 


\section{REFERENCES}

1. Aldabal L, Bahammam AS. Metabolic, endocrine, and immune consequences of sleep deprivation. Open Respir Med 7 2011;5(1):31-43.

2. Murali NS, Svatikova A, Somers VK. Cardiovascular physiology and sleep. Front Biosci 2003;8(6):s636-52.

3. Pulak LM, Jensen L. Sleep in the Intensive Care Unit: A Review. 7 Intensive Care Med 2016;31(1):14-23.

4. Elliott R, McKinley S, Cistulli P. The quality and duration of sleep in the intensive care setting: an integrative review. Int 7 Nurs Stud 2011;48(3):384-400.

5. Elliott R, McKinley S, Cistulli P, Fien M. Characterisation of sleep in intensive care using 24-hour polysomnography: an observational study. Crit Care 2013;17(2):R46.

6. Javadi N, Darvishpour A, Mehrdad N, Lakeh NM. Survey of Sleep Status and its Related Factors among Hospitalized Patients with Heart Failure. 7 Tebran Heart Cent 2015;10(1): $9-17$.
7. Lei Z, Qiongjing Y, Qiuli W, et al. Sleep quality and sleep disturbing factors of inpatients in a Chinese general hospital. 7 Clin Nurs 2009;18(17):2521-9.

8. Manian FA, Manian CJ. Sleep quality in adult hospitalized patients with infection: an observational study. Am $\mathcal{F} \mathrm{Med} S c i$ 2015;349(1):56-60.

9. Norton C, Flood D, Brittin A, Miles J. Improving sleep for patients in acute hospitals. Nurs Stand 2015;29(28):35-42.

10. Yilmaz M, Sayin Y, Gurler H. Sleep quality of hospitalized patients in surgical units. Nurs Forum 2012;47(3):183-92.

11. DuBose JR, Hadi K. Improving inpatient environments to support patient sleep. Int 7 Qual Health Care 2016;28(5): 540-53.

12. Freedman NS, Kotzer N, Schwab RJ. Patient perception of sleep quality and etiology of sleep disruption in the intensive care unit. Am 7 Respir Crit Care Med 1999;159(Pt 4 1):1155-62.

13. Bano M, Chiaromanni F, Corrias M, et al. The influence of environmental factors on sleep quality in hospitalized medical patients. Front Neurol 2014;5:267. 